\title{
A ESCRAVIDÃO NA DOUTRINA DA IGREJA: TEMAS E QUESTÕES EM DEBATE DA ANTIGUIDADE À ÉPOCA MODERNA
}

\author{
Ana Margarida Pereira ${ }^{1}$
}

Resumo: a atuação histórica da Igreja e os princípios do Cristianismo acerca da escravidão têm sido objeto de debate desde o séc. XVIII. Neste artigo, mencionaremos alguns dos autores que, da Antiguidade à Idade Média, reflectiram sobre o assunto, analisando sua influência na Modernidade. Abordaremos, em particular, as questões que monopolizaram a atenção dos autores modernos, a saber: a legitimidade da escravidão, ligada à discussão acerca da "guerra justa" e dos "justos títulos" para a redução dos indivíduos à escravidão; o batismo dos escravizados e o pagamento do dízimo, obrigatório para todos os cristãos. Analisando os testemunhos de doutrinadores da Igreja e informações colhidas em outras fontes, procuraremos mostrar que, na época moderna, se procurou, em grande medida, conciliar os princípios doutrinários, de natureza teológica e moral, com os interesses econômicos e políticos na defesa do sistema de exploração escravista.

Palavras-chave: Cristianismo. Escravidão. Justos títulos. Batismo. Dízimo.

\section{SLAVERY IN THE CHURCH'S DOCTRINE: THEMES AND ISSUES IN DEBATE FROM ANTIQUITY TO THE MODERN AGE}

\begin{abstract}
The historical role of the Church and the Christian view on slavery have been the subject of debate since the 18th century. In this article, we will mention some of the authors who, from Antiquity to the Middle Ages, reflected on the subject, analysing their influence on Modernity. In particular, we will address the issues that monopolized the attention of modern authors, namely: the legitimacy of slavery, linked to the discussion of "just war" and the "just titles" to enslave individuals; the baptism of the enslaved and the tithing, mandatory for all Christians. Analysing the testimonies of Church indoctrinators and information gathered from other sources, we will try to show that, in the modern age, there was a great attempt to reconcile doctrinal principles, of a theological and moral nature, with the economic and political interests in defence of the slavery system.
\end{abstract}

Keywords: Christianism. Slavery. Just titles. Baptism. Tithe.

\section{L'ESCLAVAGE DANS LA DOCTRINE DE L'ÉGLISE: THÈMES ET QUESTIONS EN DISCUSSION DE L'ANTIQUITÉ À L'AGE MODERNE}

Resumé: Le rôle historique de l'Église et les principes du christianisme sur l'esclavage font l'objet de débats depuis le XVIIIe siècle. Dans cet article, nous citerons certains des auteurs qui, de l'Antiquité au Moyen Âge, ont réfléchi sur le sujet, analysant leur influence sur la Modernité. En particulier, nous aborderons les questions qui monopolisaient l'attention des auteurs modernes, à savoir: la légitimité de l'esclavage, liée à la discussion de la «guerre juste» et des «justes titres» pour réduire les individus à l'esclavage; le baptême des esclaves et la dîme, obligatoire pour tous les chrétiens. En analysant les témoignages des endoctrineurs de l'Église et les informations recueillies auprès d'autres sources, nous essaierons de montrer que, à l'ère

\footnotetext{
${ }^{1}$ Possui graduação em História pela Faculdade de Letras - Universidade de Coimbra (1996) e mestrado em História da Expansão Portuguesa pela Faculdade de Letras - Universidade de Coimbra (2001). Actualmente encontra-se a preparar a sua tese de Doutorado, a ser apresentada na Faculty of Humanities Universiteit van Amsterdam. Tem experiência nas áreas de História/Pesquisa Histórica, com ênfase em História da Expansão Portuguesa e História da Escravidão na Época Moderna, desenvolvendo as suas pesquisas em torno dos seguintes temas: escravidão no império português, Igreja e missionação, Inquisição, Brasil-colónia.
}

Revista Escritas do Tempo - v. 1, n. 3, nov/2019-fev/2020 - p. 8-33 
moderne, il y a eu une grande tentative de concilier les principes doctrinaux, de nature théologique et morale, avec les intérêts économiques et politiques pour défendre le système esclavagiste d'exploitation du travail.

Mots-clés : Christianisme. Esclavage. Justes titres. Baptême. Dîme.

\section{ESCLAVITUD EN LA DOCTRINA DE LA IGLESIA: TEMAS Y CUESTIONES EN DEBATE DE LA ANTIGÜEDAD AL TIEMPO MODERNO}

Resumen: El papel histórico de la Iglesia y los principios del cristianismo sobre la esclavitud han sido objeto de debate desde el siglo XVIII. En este artículo, mencionaremos algunos de los autores que, desde la Antiguiedad hasta la Edad Media, reflexionaron sobre el tema, analizando su influencia en la Modernidad. En particular, abordaremos los temas que acapararon la atención de los autores modernos, a saber: la legitimidad de la esclavitud, vinculada a la discusión de la "guerra justa" y de los "justos títulos" para reducir a los individuos a la esclavitud; el bautismo de los esclavos y el diezmo, obligatorio para todos los cristianos. Analizando los testimonios de los adoctrinadores de la Iglesia y la información recopilada de otras fuentes, intentaremos mostrar que, en la era moderna, hubo un gran intento de conciliar los principios doctrinales, de naturaleza teológica y moral, con los intereses económicos y políticos en defensa del sistema de explotación esclavista.

Palabras-clave: Cristianismo. Esclavitud. Justos títulos. Diezmo.

\section{Estudos: uma contextualização breve}

As referências à escravidão nos textos bíblicos, as posições veiculadas por intermédio dos mesmos, quer em relação a este regime de exploração do trabalho, quer em relação aos seus protagonistas (senhores e escravos), a atuação histórica da Igreja e os princípios defendidos por ela - acerca da instituição escravista já mereceram a atenção de numerosos autores. ${ }^{2}$ A propósito de tais assuntos, a disputa entre pontos de vista contraditórios tem sido, aliás, frequente, chegando mesmo, em alguns casos, a assumir foros de controvérsia.

A discussão emergiu, sobretudo, a partir da segunda metade do século XVIII e, desde então, tem sido periodicamente reavivada, opondo os defensores do humanitarismo cristão àqueles que negam à Igreja um papel determinante no combate ao escravismo. No Brasil, atingiu o seu ápice durante o século XIX, com escravocratas e

\footnotetext{
${ }^{2}$ Referimo-nos aqui, unicamente, à Igreja Católica. As igrejas evangélicas desempenharam um papel importante nas colónias anglo-saxónicas, designadamente por intermédio das congregações criadas por ou direcionadas aos escravos africanos e seus descendentes, mas o seu estudo não cabe no âmbito deste artigo (LINCOLN \& MAMIYA, 1990; RABOTEAU, 2004). O mesmo vale para a Black Theology ou «Teologia Negra», que se desenvolveu em ligação com o movimento dos direitos civis e outros, a partir de meados do séc. XX, nos Estados Unidos da América e na África do Sul (encontrando-se igualmente presente, ainda que com menor expressão, em outros países do continente africano, na América do Sul e no Caribe), sobre a qual existe uma vasta bibliografia (COPELAND, 1994, p. 91-96).
}

Revista Escritas do Tempo - v. 1, n. 3, nov/2019-fev/2020 - p. 8-33 
abolicionistas - dentro da Igreja e fora dela - a invocarem em seu favor os textos bíblicos que, assim, eram usados para sustentar posições diametralmente opostas. ${ }^{3}$

A Igreja foi, de resto, alvo de severas diatribes por parte dos abolicionistas brasileiros, que a acusavam de pactuar - quanto mais não fosse, por omissão - com o sistema escravista (NABUCO, [1883] 2000, p. 9), mas a difusão das ideias emancipacionistas acabaria por proporcionar um reexame crítico das posições historicamente assumidas pela instituição relativamente à «questão escrava». Ainda assim, a discussão sobre a escravidão na Bíblia manteve-se no século XX e, embora atenuada, chegou até os nossos dias (HAYNES, 2002; GOLDENBERG, 2003; JOHNSON, 2004; WHITFORD, 2009).

Além das referências bíblicas sobre o assunto, a posição adotada pela Igreja primitiva (até o $1^{\circ}$ Concílio de Niceia, 325) quer em relação aos indivíduos escravizados quer em relação ao próprio sistema escravista e o papel do Cristianismo na decadência da escravidão antiga são alguns dos temas em torno dos quais se desenvolveu o debate. O posicionamento teórico da instituição e sua atuação face ao aumento maciço do número de seres humanos reduzidos ao cativeiro no decurso da época moderna; os princípios por ela defendidos relativamente aos indígenas americanos, de um lado, e aos naturais do continente africano, do outro; e a influência dos autores cristãos e de suas concepções sobre a escravidão na sociedade da época, através do tratamento por esta dispensado a seus escravos e do lugar que lhes atribuiu no corpo social, são outros temas que, desde há muito, têm chamado a atenção dos historiadores.

Para alguns, o Cristianismo seria, em sua essência, contrário aos princípios sobre os quais assentava o regime escravista, porque além de eleger a caridade e o amor ao próximo como virtudes fundamentais, preconiza a igualdade dos homens perante Deus: o que, apesar de deslocar a sua concretização para "a outra vida", teria incentivado, igualmente, a busca da igualdade no plano terreno, colocando-a como um objetivo a

\footnotetext{
${ }^{3}$ A produção em causa é muito extensa. No que diz respeito ao Brasil, um dos que, enquanto eclesiástico, mais se evidenciou na defesa do tráfico negreiro e da exploração do trabalho escravo foi D. José Joaquim da Cunha de Azeredo Coutinho (1742-1821), bispo de Pernambuco entre 1798 e 1802 e, mais tarde, inquisidor-geral do Reino (COUTINHO, 1808a e 1808b; SIQUEIRA, 1965, p. 147-213). No campo oposto, encontramos nomes ligados à ala radical da Igreja que, nos pasquins revolucionários em circulação por todo o território antes e depois da independência, davam voz aos anseios das camadas inferiores da sociedade, designadamente os escravos. A posição da Igreja e a doutrina por ela preconizada a respeito da escravidão conheceriam, de resto, uma evolução significativa ao longo do séc. XIX, com a aceitação cada vez mais ampla, entre seus representantes, do princípio segundo o qual a escravidão era, por sua própria natureza, contrária aos ensinamentos do Evangelho (COSTA, 2008, p. 20-22).
}

Revista Escritas do Tempo - v. 1, n. 3, nov/2019-fev/2020 - p. 8-33 
alcançar "nesta vida" (CARVALHO, 1988). Pelo contrário, outros defendem que o Cristianismo não era incompatível com o sistema escravista e que o declínio da escravidão antiga se deveu a fatores econômicos (o desenvolvimento das forças produtivas) e não à influência religiosa do Cristianismo (CICCOTTI, 1910). Alguns autores assinalam, mesmo, que a escravidão tem sido aceite como uma prática natural pela religião dominante em diferentes sociedades (GILBERTSON, 1974, p. 601); isso mesmo teria acontecido, também, com o Cristianismo, uma religião cujo crescimento inicial se deu no âmbito de uma sociedade - a romana - em que o recurso ao trabalho escravo era corrente e que, além disso, para se impor, desenvolveu uma estratégia que assentava, em grande medida, na aproximação ao poder político e na defesa da ordem vigente.

Neste artigo, não é nosso objetivo aduzir argumentos que sustentem uma das duas linhas de interpretação, excluindo a outra. Aliás, julgamos que a recomendação feita por Eugene D. Genovese (1976, p. 159-324) a propósito do Sul dos Estados Unidos também é válida para outros lugares, podendo aplicar-se com proveito às colônias ibero-americanas e não só. ${ }^{4}$ Assim, limitar-nos-emos a apresentar as ideiaschave do pensamento cristão relativamente ao sistema escravista de exploração do trabalho, bem como seus desdobramentos ao longo do tempo, para podermos determinar em que medida as concepções herdadas de períodos anteriores influenciaram ou não a doutrina da Igreja e as reflexões a esse propósito produzidas no seio da instituição durante a época moderna.

Neste sentido, procuraremos identificar as questões em torno das quais se desenvolveu a discussão a partir do início da expansão ibérica, analisando as perspectivas em discussão e suas relações com a história do pensamento cristão. $\mathrm{O}$ debate paralelo sobre o estatuto jurídico dos ameríndios e dos africanos escravizados, bem como as posições assumidas pela Igreja relativamente a uns e a outros, não serão objeto de análise neste artigo. Por outro lado, também não é nossa intenção abordar, de forma sistemática, o pensamento dos autores que, na Europa e fora dela, refletiram sobre a escravidão a partir do século XVI, mas assinalar a existência de continuidades no âmbito do pensamento cristão que forneceriam o lastro sobre o qual se desenrolaria o

\footnotetext{
${ }^{4}$ Embora defenda que o Cristianismo é politicamente conservador e promove a submissão, elevando-a à condição de dever moral, o autor também chama a atenção para outros elementos nele presentes, como a ideia de igualdade espiritual e de liberdade da alma, e para o seu legado de resistência, defendendo a necessidade de adotar uma perspectiva ampla e equilibrada, sob pena de "surrender all chance to understand the contribution of Afro-American Christianity to the survival and mobilization of black America" (GENOVESE, 1976, p. 163).
} 
debate no período moderno, orientando a atuação da Igreja e também, em boa medida, das autoridades civis.

\section{Perspectiva histórica}

O Cristianismo nasceu no seio do mundo judaico do Próximo Oriente; aí, como em muitas outras sociedades da época, a escravidão era uma prática admitida, embora a lei distinguisse os israelitas dos não-israelitas - os primeiros serviam como escravos durante um período máximo de sete anos, após o qual tinham a possibilidade de optar por permanecer ou não na posse do senhor; os segundos podiam manter-se como escravos indefinidamente.

O Antigo Testamento absorveu as disposições contidas na legislação hebraica a propósito da escravidão; o Novo Testamento também apresenta diversas referências ao assunto - a mais conhecida das quais se encontra na "Epístola a Filémon", que integra o chamado Corpus Paulinum -, mas nenhuma condenação explícita do sistema. Na verdade, a distinção entre homem livre, servo e escravo não alcançara, ainda, o seu desenvolvimento pleno (SPICQ, 1978, p. 201-226); por outro lado, a economia do Império Romano assentava, em grande medida, na exploração do trabalho escravo (usado na produção agrícola em larga escala, na pecuária, na indústria e nas atividades domésticas) e qualquer tentativa para o eliminar criaria, naturalmente, instabilidade.

As perseguições que caracterizaram os primeiros tempos da história do Cristianismo promoveram uma aproximação entre os fiéis que, em alguns casos, se traduziu no estabelecimento de uma cumplicidade muito estreita entre senhores e escravos unidos pela partilha da mesma fé. ${ }^{5}$ No entanto, com o fim das perseguições, os autores cristãos passaram a apoiar, de forma cada vez mais explícita, a ordem estabelecida, desvalorizando os aspectos negativos da escravidão que, antes, haviam agitado suas consciências, dando lugar a manifestações piedosas, por intermédio das quais exprimiam sua sensibilização com o sofrimento dos escravos.

A Igreja primitiva não vedou o acesso a suas fileiras por parte de cativos e libertos. Pregando o desprezo do mundo - ao mesmo tempo que nele conquistava o seu espaço, adquirindo expressão institucional e uma visibilidade e influência cada vez mais significativas, graças à penetração da mensagem cristã, mas também às ligações

\footnotetext{
${ }^{5}$ O Cristianismo surgiu como uma seita judaica no governo de Augusto (27 a.C.-14 d.C.), se convertendo em religião autônoma após sua morte. Por rejeitarem a divindade imperial, defendendo que a palavra de Cristo era a única verdade, os cristãos foram tidos como rebeldes e perseguidos pelos romanos até o início do século IV, quando o imperador Constantino estabeleceu a liberdade de culto no Édito de Milão (313).
} 
estabelecidas com a esfera do poder - exortava, porém, os escravos a acatarem a sua sorte, obedecendo de boa vontade aos senhores, e não estes a libertarem-nos. Ou seja, aceitava sem sobressaltos de maior uma instituição que, além de integrar a estrutura social, era admitida pelas concepções mentais da época. Aliás, de acordo com os princípios adotados pela instituição, a conversão ao Cristianismo não garantia, por si só, a libertação da pessoa escravizada. ${ }^{6}$

Com a suspensão das campanhas militares, a partir do reinado de Augusto (27 a.C.-14 d.C.), o Império Romano viu-se privado de uma de suas principais fontes de obtenção de escravos - a guerra. Muitos senhores teriam, então, passado a adotar formas de tratamento mais brandas, a fim de preservarem seus plantéis. Por outro lado, a legislação imperial conheceu, também, alguns avanços, com a elaboração de medidas destinadas a reduzir a violência sobre os cativos que resultavam: em primeiro lugar, do lento processo de passagem da escravidão à liberdade, por intermédio da servidão, iniciado com o fim da expansão territorial do império; e, em segundo lugar, da influência do Estoicismo, mais visível a partir de Adriano (76-138).

Os estoicos, que tiveram em Séneca (4 a.C.-65 d.C.) sua figura mais proeminente, recusavam o princípio da «escravidão natural», mas admitiam a «escravidão legal», embora considerassem que esta derivava da «escravidão moral» que, por sua vez, resultaria da sujeição da alma em relação ao corpo, exprimindo a vitória do desejo e a rendição do homem aos prazeres do mundo. Assim, se, por um lado, increpavam os senhores, reprovando-lhes a brutalidade no trato com os escravos, que tinham como reflexo de sua própria miséria moral, por outro, dirigindo-se aos escravos, recomendavam-lhes obediência para com os seus senhores. Transpondo para a relação senhor/escravo a oposição - de carácter ético - entre alma e corpo, mantiveram a concepção aristotélica do escravo como instrumento do senhor e extensão de seu próprio corpo, assegurando a preservação da ordem social. A valorização da ideia de «natureza»e da «vida natural», que se ligava à pobreza, entendida como satisfação com o que se possui e desprendimento em relação às coisas materiais, terrenas, serviria, de

\footnotetext{
${ }^{6}$ Alguns partidários da instituição afirmam que o espírito do Cristianismo exalta naturalmente a liberdade e que a Igreja primitiva não condenou o sistema escravista unicamente porque receava questionar a ordem estabelecida (AGATE, 1974, p. 603). David Brion Davis (2001, p. 109), depois de assinalar que "muitos historiadores exageraram a antítese entre a escravidão e a doutrina cristã" e que a contradição reside na própria ideia de escravidão, afirma, por seu lado, que: "O cristianismo proporcionou um modo de responder a essa contradição, e continha racionalizações para a escravatura assim como ideais que eram potencialmente abolicionistas. No entanto, a questão significativa é que atitudes voltadas para a escravidão eram entrelaçadas com os conceitos religiosos centrais”.
}

Revista Escritas do Tempo - v. 1, n. 3, nov/2019-fev/2020 - p. 8-33 
resto, o mesmo objetivo, articulando-se com a visão estoica do escravismo (FINLEY, 1991, p. 126; JOLY, 2007, p. 98-114).

A escravidão aparece, com frequência, nas obras dos autores que marcaram os primeiros séculos do Cristianismo - os chamados «Padres da Igreja». As reflexões por eles produzidas a propósito da matéria não introduziram, porém, inovações significativas em relação aos princípios defendidos pelos estoicos romanos, cuja influência no pensamento cristão foi, de resto, muito sensível (FINLEY, 1991, p. 125). ${ }^{7}$

Concentrando a análise nos direitos e deveres mútuos que, em seu entender, deveriam pautar a relação senhor/escravo, os Padres da Igreja foram, igualmente, influenciados pela herança dos filósofos gregos, designadamente Platão (428/427 a.C.348/347 a.C.) e Aristóteles (384 a.C.-322 a.C.). O primeiro considerava que a escravidão era uma instituição necessária, porquanto os trabalhos manuais, tidos como inferiores, eram incompatíveis com a condição do homem livre; o segundo criou o princípio da «escravidão natural», a que já nos referimos, o qual seria, depois, retomado por São Tomás de Aquino (1225-1274), adquirindo larga aceitação entre os autores cristãos até a época moderna. ${ }^{8}$

Segundo Aristóteles, a distinção entre o homem livre e o escravo era de tipo ontológico, isto é, tinha origem na própria natureza, que destinaria a cada um seu lugar, de acordo com as faculdades que lhe eram atribuídas ao nascer. Sendo uma instituição natural, a escravidão era, assim, naturalmente boa e justa. Além disso, comportava vantagens para ambos, senhor e escravo, porque aliava a inteligência e as virtudes do primeiro à força física do segundo que, como instrumento de seu senhor, executava as ordens que dele recebia. Não tendo capacidades para mais, estava destinado a obedecerlhe - disso dependia a sua própria segurança - como o senhor, pela sua razão e previdência, o estava também a mandar (SMITH, 1983, p. 109-122).

Por sua vez, a doutrina cristã defenderia, mais tarde, uma tese cujo parentesco com esta se nos mostra evidente: aqueles que, devido a sua inferioridade (moral e

\footnotetext{
${ }^{7}$ David Brion Davis (2001, p. 104-105) assinala, no entanto, que o Cristianismo "elevava a obediência, a humildade, a paciência e a resignação para o plano das altas virtudes"; desta forma, conferia "uma certa dignidade moral à servidão", afastando-se da atitude corrente entre os romanos, para quem "o caráter servil era sinônimo de tudo que fosse humilde e corrompido".

${ }^{8}$ Juan Ginés de Sepúlveda (1494-1573) foi um dos autores que legitimaram a escravidão com base em Aristóteles e no princípio da escravidão natural (KAPP, 2013, p. 123-128, 136). Moses I. Finley (1991, p. 20-21), relativiza, porém, a influência do pensamento aristotélico nos autores cristãos, afirmando que: "para os defensores da escravidão, Aristóteles fornecia apenas um ornamento culto ao argumento principal, que se baseava nas Escrituras. Para justificar a escravização de algumas das criaturas de Deus era necessário o apoio divino, e não a história ou filosofia pagãs, que não conheciam nem pecado nem batismo".
}

Revista Escritas do Tempo - v. 1, n. 3, nov/2019-fev/2020 - p. 8-33 
intelectual), fossem incapazes de governar-se a si próprios deveriam ser guiados pelos que lhes eram superiores (SIERRA BRAVO, 1967, p. 210 e 774). ${ }^{9}$ A escravidão constituía, portanto, um castigo, mas era, simultaneamente, um meio para atingir a salvação.

Ambrósio de Milão (339-397), Santo Agostinho (354-430) e Santo Isidoro de Sevilha (460-536) instituíram a tese segundo a qual a escravidão era consequência do pecado original (CORCORAN, 1985; HAYNES, 2003, p. 7). São Gregório Magno (540-604) afirmou, mesmo, que aqueles que se viam reduzidos à condição de escravos não só mereciam sê-lo, como disso tinham necessidade. No entanto, se, por um lado, chamava a atenção dos cativos para a humildade de seu estatuto e para a obrigação, dele decorrente, de obedecerem fielmente a seus amos, por outro, exortava também os senhores, lembrando-lhes que entre eles e seus escravos não havia distinção, pois a natureza os fizera iguais, e declarava-os "conservos dos seus servos" na adoração ao Senhor dos senhores (apud SIERRA BRAVO, 1967, p. 931).

Antes dele, São Basílio (330-379) afirmara já que: “aunque uno se llame señor y otro siervo, todos, sin embargo, en cuanto somos de la misma condición y en cuanto esclavos de quien nos ha creado, somos compañeros de servidumbre", explicitando, assim, o princípio segundo o qual todos os homens são iguais perante Deus (apud SIERRA BRAVO, 1967, p. 210-211). Santo Agostinho reforçá-lo-ia, argumentando que nem o senhor era verdadeiramente senhor, nem o escravo que o servia um mero escravo, na medida em que a relação entre eles existente assentava em laços de dependência mútua, ou seja, um tinha necessidade do outro e ambos de Deus, o único e verdadeiro senhor, que se encontrava acima de qualquer necessidade (CORCORAN, 1985, p. 34$35)$.

Por outro lado, São Gregório de Nissa (ca. 335-394) e São João Crisóstomo (344-386) opuseram-se ao sistema escravista de exploração do trabalho, insistindo na ideia da igualdade dos homens enquanto seres criados à imagem e semelhança de seu Criador (SIERRA BRAVO, 1967, p. 265-266 e 502-503). Embora tivesse sido partilhada por outros, a posição por eles assumida permaneceria, no entanto, minoritária (GARNSEY, 1999).

\footnotetext{
${ }^{9}$ No entanto, a existência de uma ordem natural, que determinava a submissão dos menos dotados, não autorizava seus superiores a exercerem sobre eles um domínio absoluto; antes pelo contrário, tinham o dever de protegê-los, sob pena de se tornarem maus cristãos (CORCORAN, 1985, p. 32-33). A este propósito, veja-se, por exemplo, o pensamento de Bartolomeu de Las Casas (1474-1566) (KAPP, 2013, p. 124).
}

Revista Escritas do Tempo - v. 1, n. 3, nov/2019-fev/2020 - p. 8-33 
Durante a Idade Média, a doutrina da Igreja a propósito da escravidão seria, de fato, dominada pelo pensamento de São Tomás de Aquino que, como vimos, foi fortemente influenciado pela filosofia aristotélica. Embora defendesse a crença na unidade intrínseca da espécie humana, vendo a escravidão como um desvio ao jus naturale (direito natural), o teólogo dominicano aceitou a submissão escravista enquanto princípio instituído pelo jus gentium (direito das gentes), considerando-a natural e justa pela utilidade de suas consequências, tanto para os senhores como para os escravos. Apoiando-se nas Escrituras, salientou, ainda, a distinção que nelas se fazia entre a «escravidão do corpo» e a «escravidão da alma», defendendo que a sujeição do corpo não era incompatível com a liberdade da alma, alcançada por intermédio do Cristianismo (BRETT, 1994; DAVIS, 2001, p. 105).

Aliás, para a doutrina cristã, a liberdade original da alma era essencialmente inabalável, como inabalável era, também, o princípio da igualdade dos homens perante Deus. ${ }^{10}$ Sendo o plano espiritual, da alma, superior ao plano material, do corpo, a submissão terrena de um homem a outro, por intermédio da escravidão, era objetivamente indiferente. Ou antes: se essa possibilidade se encontrava contemplada nas leis dos homens, o Cristianismo que, entre outras coisas, deveria zelar pela conservação da lei, isto é, da ordem estabelecida, não poderia logicamente opor-se à existência de pessoas escravizadas. ${ }^{11}$

Estas concepções seriam, de resto, integradas no Direito Canônico medieval. O Decreto de Graciano (século XII), cuja importância foi fundamental para a estabilização do Direito Canônico, sistematizando, pela primeira vez, suas fontes e conteúdos,

\footnotetext{
${ }^{10}$ Um episódio ocorrido no recôncavo da Guanabara, na segunda metade do século XVIII, nos oferece um testemunho pitoresco acerca da vulgarização deste princípio entre a população leiga, designadamente entre os indivíduos escravizados, bem como o seu enraizamento e persistência ao longo do tempo: João Nunes da Rosa, administrador da capela de Nossa Senhora da Soledade (em Tapacurá, no atual município de Itaboraí), preparava a capela para a chegada do visitador enviado pelo bispo, que se encontrava na freguesia; estando a limpar um crucifixo, passou pelas proximidades Joaquim, negro, escravo do capitão Joaquim Luís Furtado de Mendonça, que servia como pastor de gado ou curraleiro, a quem chamou, dizendo: "ó Joaquim vem cá, tu conheces a este?". A resposta do escravo, segundo disse depois uma testemunha, foi pronta: "pois não hei de conhecer, que he seu senhor, e mais meu?". Este episódio é tanto mais interessante quanto, segundo afirmou o próprio administrador, o escravo, natural de Angola, era "ahinda bruto", presumindo-se de suas palavras que o contato dele com o Catolicismo deveria ser relativamente recente. ANTT, TSO, IL, Processos, n. 3641 (24/05/1781-21/08/1786), fl. não num.; n. 5635 (14/05/1784-20/03/1786), fl. 5-5v (grifo nosso).

${ }^{11}$ Santo Agostinho considerava mesmo que, ao obedecer a seu senhor, o escravo obedecia, em última análise, a Deus: se tratava, portanto, de uma decisão livre e voluntária, de fundo religioso (o amor de Deus), e não motivada pelo medo do castigo. Em termos concretos, a escravidão se tornava, assim, irrelevante, mesmo porque a obediência a um senhor terreno correspondia a uma situação que, além de transitória, era condicional, isto é, o indivíduo escravizado poderia e deveria recusar-se a cumprir ordens injustas, que violassem a lei divina (CORCORAN, 1985, p. 36-38).
} 
ignorou a escravidão enquanto instituição jurídica, tomando-a como um fato natural. De uma maneira geral, o Direito Canônico se limitava a proclamar a igualdade fundamental de todos os homens perante Deus e, embora alguns canonistas observassem que a realização de certos atos por parte dos escravos era incompatível com sua condição, tal como a definia o Direito Civil, esta não sofreu qualquer contestação.

A escravidão não desapareceu da Europa ocidental durante a Idade Média, mas o trabalho escravo foi, em grande medida, substituído por diversas formas de servidão, que vinculavam o trabalhador à terra. Com o advento da época moderna, se assistiria, porém, a um desenvolvimento sem precedentes do sistema escravista que, durante três séculos, permitiu a exploração econômica do Novo Mundo, onde sua preponderância foi mais acentuada, se traduzindo na deslocação forçada de uma enorme massa humana, cujos integrantes, em sua grande maioria africanos, foram arrancados a seus lugares de origem para serem utilizados como mão de obra escrava ao serviço dos poderes colonizadores.

O desenvolvimento da escravidão na época moderna teve efeitos devastadores sobre suas vítimas, mas, ao mesmo tempo, exerceu também um forte impacto no homem europeu, contribuindo para a alteração de seus quadros mentais, associada aos contatos e experiências proporcionados pela Expansão, e para o reexame crítico de valores que até então haviam permanecido inalterados. Neste sentido, a discussão em torno do conceito de «guerra justa» assumiu uma importância particular, dominando as reflexões produzidas por muitos dos autores que, na época, se interessaram pelo problema do escravismo e, em termos gerais, pelas questões decorrentes do contato com os habitantes dos territórios ultramarinos (RUSSELL-WOOD, 1978, p. 22-23).

\section{Questões em debate}

Guerra justa: Até o advento da época moderna, o conceito de «guerra justa» se mantivera estreitamente associado às lutas entre cristãos e muçulmanos: para os monarcas portugueses e, de uma maneira geral, para os cristãos, as ofensivas contra o "Infiel" se destinavam a garantir a defesa da fé, constituíam um serviço a Deus e, como tal, eram eminentemente justas. Assim, a expansão no Norte de África seria a continuação da luta pela reconquista da Península Ibérica, tendo como objetivos a "libertação" dos lugares ali ocupados pelos muçulmanos e a sua reintegração na esfera cristã (BRÁSIO, 1961, p. 102-106). Nesse sentido, os prisioneiros capturados pelos portugueses em Marrocos podiam ser legitimamente reduzidos à escravidão.

Revista Escritas do Tempo - v. 1, n. 3, nov/2019-fev/2020 - p. 8-33 
O avanço para Sul, ao longo da costa ocidental da África, o contato com povos e culturas alheios ao mundo islâmico e o entabulamento de relações comerciais que proporcionavam o acesso aos escravos por via da troca pacífica com as redes locais levariam, porém, a um reajustamento do discurso político, tendo em vista a defesa do projeto expansionista dos portugueses e a afirmação de sua legitimidade. A ideologia de Cruzada daria lugar a uma concepção mais ampla, que repercutia a convicção segundo a qual Portugal era uma nação eleita e os portugueses o instrumento escolhido por Deus para difundir Sua mensagem pelo mundo.

A proteção divina conferia às ações levadas a cabo pelos portugueses no Ultramar um significado espiritual com ressonância à escala global - embora fosse invocada, com frequência, para justificar atos cujas motivações eram claramente menos elevadas, correspondendo a interesses econômicos, estratégicos e de natureza política. A teoria da «restituição», que legitimara as campanhas no Marrocos, se estendeu, de resto, à África subsaariana, ao Oriente e depois, também, ao Brasil, com a procura do reino do Preste João e a difusão de lendas que atribuíam ao apóstolo Tomé a introdução do Cristianismo na Índia e entre os indígenas do futuro território brasileiro (BEBIANO, 2000, p. 123-179).

A chancela papal era indispensável para legitimar as atividades dos portugueses na costa ocidental da África, com a ratificação dos princípios por eles sustentados. A concorrência de outras nações europeias e a necessidade de garantir o monopólio do comércio na região foram outros motivos que os levaram, desde logo, a procurar o apoio do Papado. As concessões sucessivamente outorgadas por diversos papas aos monarcas lusitanos materializavam, assim, o apoio da Igreja e a sua adesão ao projeto expansionista português. Com consequências duradouras, tiveram um impacto que ultrapassou o aspecto político, se fazendo sentir, igualmente, em outros domínios, de que a economia é um exemplo. Outro é a ação militar. Além disso, como assinala A. J. R. Russell-Wood (1978, p. 23-29), se refletiram - de forma muitas vezes dramática, acrescentamos nós - nas relações dos portugueses com os povos "não-cristãos" e "nãobrancos" com os quais entraram em contato através da Expansão.

Eugénio IV (1383-1447), pela bula Rex regum, de 8 de setembro de 1436, formalizou o apoio do Papado ao projeto para a conquista de Tânger, que redundaria numa pesada derrota para os portugueses, atribuindo a D. Duarte (1391-1438) e seus sucessores a posse das terras que, na África, por estes fossem conquistadas aos muçulmanos e não só - "homines Sarracenos Agarenos et alios infideles”, segundo a 
expressão usada no diploma (MARQUES, 1944, p. 365-369). Pela Preclaris tue devotionis, de 25 de maio de 1437, lhe concederia, bem como a seus vassalos, autorização para comerciarem com todos os sarracenos e infiéis ("saracenis et infidelibus"), estabelecendo com eles contratos, comprando-lhes mercadorias e indo a suas terras para lá lhes venderem as suas, com a excepção de alguns produtos, cuja venda era interdita (ferramentas, madeiras, cordame, navios e todo o tipo de armas) (MARQUES, 1944, p. 378-380). Nicolau V (1397-1455), pela bula Dum diversas, de 18 de junho de 1452, dirigida a D. Afonso V (1432-1481), lhe concedia direitos de conquista sobre todas as terras que se encontrassem na posse de "sarracenos, pagãos, infiéis e de quaisquer inimigos de Cristo", com permissão plena para as "invadir, expugnar, subjugar [e] reduzir seus habitantes a perpétua servidão" (JORDÃO, 1868, p. 22-23; BRÁSIO, 1961, p. 112-114).

A bula Romanus pontifex, de 08 de janeiro de 1455, apontada como "a Magna Carta jurídica da criação do Império Ultramarino de Portugal” (BRÁSIO, 1961, p. 115), confirmava as prerrogativas anteriormente concedidas, atribuindo a $\mathrm{D}$. Afonso $\mathrm{V}$ e seus sucessores, bem como ao infante D. Henrique (1394-1460), a posse exclusiva de todas as terras, portos, ilhas e mares conquistados ou a conquistar desde o cabo Bojador e o cabo Não para o Sul, em direção às regiões meridionais do continente africano. Ao mesmo tempo, lhes conferia o monopólio do comércio com os habitantes dos territórios conquistados, reiterando a autorização para atacarem e subjugarem "quaisquer sarracenos ou pagãos e outros inimigos de Cristo onde-quer-que estivessem estabelecidos (...) e outrossim que [pudessem] reduzir a escravidão perpétua as suas pessoas". Os frutos obtidos com os habitantes da costa da Guiné - onde, nos anos anteriores, os portugueses haviam adquirido muitos negros que daí foram transportados para o Reino e, em sua maior parte, convertidos ao Catolicismo - eram, aliás, motivo de congratulação, abrindo perspectivas animadoras para o futuro: "esperando-se que, com a ajuda da clemência divina, se as coisas com êles forem caminhando dêste modo, ou aquêles povos se convertam à fé, ou pelo menos se salvem em Cristo muitas das suas almas" (JORDÃO, 1868, p. 31-34; BRÁSIO, 1961, p. 114-117).

Nesta e em outras bulas emitidas ao longo do século XV, os "benefícios espirituais" que para eles resultariam de sua entrada na comunidade dos crentes foram, de fato, o motivo invocado para justificar a escravização dos africanos não islamizados (animistas e politeístas). De acordo com a perspectiva adotada pelas autoridades portuguesas - e aceita pelo Papado -, a salvação das almas dos indivíduos escravizados 
compensava a privação de liberdade que lhes era imposta pelo cativeiro, o qual não só tinha uma justificação ética e religiosa, como representava o "meio necessário" para o alcance do objetivo desejado. Aliás, este argumento seria invocado, com frequência, não apenas pelas autoridades civis e eclesiásticas, como também por muitos intelectuais desde Gomes Eanes de Zurara (1410-1474), o autor de Crónica do Descobrimento e Conquista da Guiné (1453), que narrou de forma pungente o desembarque dos primeiros escravos no Reino, mas não deixou de assinalar as vantagens que aí lhes seriam proporcionadas, congratulando-se com a melhoria de suas condições de vida e a perspectiva da salvação de suas almas por intermédio do batismo (MEDINA, 1996, p. $37-38) .{ }^{12}$

Os próprios colonizadores se apropriavam do discurso oficial, utilizando-o para sustentar seus interesses econômicos. Um requerimento proveniente do Rio de Janeiro, no qual se assinalavam as vantagens que resultariam da instituição de uma nova Companhia para o comércio de Cacheu, na Guiné, ${ }^{13}$ exprime, de forma clara, a ideia segundo a qual a escravidão era um meio para atingir a salvação, aludindo aos "milhares de almas que a Companhia ha de resgatar desde a ilha de Bissau the Serra Leoa para virem receber o baptismo, e porem se no caminho de se poderem salvar". Sob o ponto de vista econômico, as razões que sustentavam a medida eram óbvias, pois "todos sabem o muito que são necessarios os escravos no nosso Brazil para o trabalho das lavouras das rossas, e engenhos, e para a extracção do ouro nas Minas, e disto o que redunda em conveniencias da Coroa, e bem comum dos vassallos". No entanto, além destas, apresentavam-se outras que, invocando ainda em meados do século XVIII a missão espiritual dos portugueses, conferiam dignidade a suas ambições de ordem material, justificando-as pela concretização de um bem maior, o qual era evitar que os

\footnotetext{
${ }^{12}$ Esta tendência foi contrariada, entre outros, por Fernando de Oliveira (1507-158?) em Portugal e Francisco de Vitória (1483-1546) na Espanha (KAPP, 2013, p. 138-141).

${ }^{13} \mathrm{Em}$ 1690, foi fundada a Companhia de Cacheu e Cabo Verde, que sucedeu à Companhia do Cacheu, Rios e Comércio de Guiné, cujas atividades haviam cessado em 1682. Tinha como objetivo central garantir o abastecimento de escravos ao Pará e Maranhão; mais tarde, obteve, também, o asiento ou monopólio do comércio de escravos para as Índias de Castela. Porém, sua existência não seria longa, uma vez que a acumulação de prejuízos conduziu a um rápido declínio das atividades da Companhia entre o final do séc. XVII e o início do seguinte. No entanto, o requerimento apresentado por José Gomes da Silva, a que aqui se faz alusão, mostra que, em 1748, os homens de negócio do Rio de Janeiro estavam interessados em reativar o comércio com a região, o que poderia ser o resultado de dificuldades nascidas da concorrência com os traficantes ingleses, explicitamente mencionados no documento (MAGALHÃES, 1998, p. 60-63).
} 
escravos caíssem em mãos dos ingleses e, assim, "mais infelices por isso, que pello captiveyro", fossem "morrer calvenistas". ${ }^{14}$

As discussões em torno da «guerra justa», ocorridas durante a época moderna, e o alargamento do conceito, que passou a englobar não apenas os muçulmanos, mas todos os que se opusessem à difusão do Cristianismo, foram, assim, diretamente influenciadas pela ideologia expansionista dos portugueses (e espanhóis). Por outro lado, refletiam, também, as contradições resultantes do embate entre os princípios teóricos, de natureza moral e religiosa, e os interesses práticos, ligados à emergência do capitalismo comercial e da concorrência econômica entre as potências europeias. Neste sentido, as reflexões acerca dos «títulos justos» de cativeiro constituem um desdobramento da discussão anterior, evidenciando o mesmo tipo de dúvidas e contradições análogas. Por outro lado, a importância assumida pelo tema, que monopolizou a atenção de teólogos e juristas, pode, ainda, ser vista como o resultado do desenvolvimento então alcançado pelo tráfico e da dependência das colónias americanas em relação ao trabalho dos africanos escravizados (PIMENTEL, 2007, p. 299-317).

Batismo: Além das questões relacionadas com a legitimidade do cativeiro e sua fundamentação teórica, o debate da época seria, igualmente, marcado pela discussão acerca do batismo dos indivíduos escravizados e das circunstâncias em que este lhes era ministrado. O simbolismo inerente ao ato; as dúvidas e perplexidades suscitadas pelos testemunhos dos missionários, de capitães e armadores e, entre outros, dos próprios escravizados; e os conflitos que, a este propósito, tiveram lugar entre o clero secular e os membros das ordens regulares - especialmente os jesuítas - chamaram a atenção de diversos autores interessados na questão do escravismo, justificando as suas tomadas de posição na matéria.

Os batismos em massa que eram realizados nos portos africanos antes do embarque para o Novo Mundo foram, assim, objeto de contestação: negando-se a validade deles, se apontava como condição prévia para o batismo a catequização dos escravizados, cuja adesão ao Catolicismo deveria ser voluntária e expressamente declarada. A uma concepção tradicional, centrada na dimensão ritualista da vivência religiosa, opunha-se, também neste caso, a visão reformista dos setores mais avançados da Igreja, empenhados em garantir a adesão íntima dos crentes. Mas se a atuação desenvolvida pelos representantes do clero secular pressupunha a «desafricanização»

${ }^{14}$ ANTT, MNEJ, mç. 69, n. 5, 1748, fl. não num.

Revista Escritas do Tempo - v. 1, n. 3, nov/2019-fev/2020 - p. 8-33 
instantânea dos escravizados por intermédio do batismo, negando-lhes uma identidade própria, os jesuítas não iam muito além, imbuídos que estavam da crença na superioridade da cultura de matriz cristã, inquestionável, de resto, para a maioria dos homens de seu tempo.

Na segunda metade do século XVI, se assinalava a propósito de Cabo Verde e da forma como aí eram batizados os cativos antes de serem transportados para seu destino: "en la ribera, al tiempo de embarcarlos, los bautizan a todos juntos con un hisopo - que es otra barbaridad grandísima" (MERCADO, 1977 [1571], p. 141). Algumas décadas mais tarde, o batismo dos africanos anteriormente reduzidos ao cativeiro, as circunstâncias em que tinha lugar e as características de que se revestia a cerimônia, de um e do outro lado do Atlântico, seriam minuciosamente examinados por Alonso de Sandoval, SJ (1576-1652) que desenvolveu uma atividade pioneira na assistência aos africanos desembarcados em Cartagena de Índias.

As críticas de que eram alvo os jesuítas, acusados por seus detratores (em especial, no clero secular) de batizarem indevidamente, à sua chegada à América, muitos escravizados que teriam recebido o batismo antes do embarque nos portos africanos, incorrendo assim em sacrilégio, ${ }^{15}$ o levariam a escrever um opúsculo intitulado: Pregúnta se si es lícito baptizar los morenos de Cartagena como los padres de la Compañia los baptizan (VILA VILAR, 1987, p. 21). ${ }^{16}$ Sempre que ali aportava um navio com escravos, dizia, os jesuítas tinham a preocupação imediata de averiguar se os recém-chegados iam "validamente baptisados", recorrendo para tal a intérpretes. Assim, fora possível constatar que a maioria dos que chegavam de Angola não só recebia o batismo antes de embarcar, como conhecia o significado da cerimónia, tendo

\footnotetext{
15 Além desta, havia outra acusação recorrente de que eram alvo os jesuítas, no continente americano e fora dele: a de que usurpavam as competências do clero paroquial, a quem cabia a administração do batismo. $\mathrm{O}$ assunto não seria objeto de menção no opúsculo que aqui examinamos, mas as críticas ao clero secular e, em particular, aos padres que atuavam nos portos situados ao longo da costa ocidental da África são nele evidentes.

16 Segundo Enriqueta Vila Vilar, este opúsculo, ainda inédito, se encontra no Archivum Romanum Societatis Iesu - ARSI, em Roma. Em Lisboa, no ANTT, existe um documento intitulado "Pregunta sse si es licito baptizar los morenos en esta cuydad (sic) de Cartagena de las Yndias como los padres de la Compañia de Jesus los baptizan ": trata-se da cópia de um parecer escrito no Colégio de Cartagena em 07 de junho de 1611, no qual constam os nomes de Alonso de Sandoval e de outros cinco jesuítas - Gonzalo de Lira, Hernando Núñez, Juan Antonio de Santander, Luis de Santillán e Bernabé de Rojas -, com confirmação de Baltasar Mas Burgués, Antonio Agustín, Jerónimo de la Jarraga (?) e Manuel de Arceo, dada também em Cartagena, no dia 11 de maio de 1612. Ao que tudo indica, este é o documento cujo original se encontra em Roma e, apesar de nele figurarem outros nomes, parece não haver dúvidas que Alonso de Sandoval foi efetivamente o seu autor. Confirmam-no o fato de o texto estar escrito no singular e a assinatura do próprio, no final do documento. ANTT, AJCJ, CJ, mç. 56, n. 60, 07/06/1611-11/05/1612 (as citações apresentadas foram retiradas daqui).
} 
assimilado os princípios básicos do Catolicismo antes de sua chegada à América (SANDOVAL, 1987 [1627], p. 382-383 e 387-390).

Já no que se referia àqueles cuja origem eram os Rios de Guiné, a situação se apresentava em tudo distinta: "los menos y muy pocos" (de cada 200 que ali chegavam, 12 a 14 e não mais) eram ladinos, tendo sido batizados de acordo com as regras da Igreja, havendo muitos (50, 60 e até mais, do mesmo número de 200) que nem sequer tinham recebido a água do batismo antes de serem embarcados. Os casos mais numerosos - "muchos en cada armazon" - eram aqueles em que o batismo fora feito de forma inválida no porto de embarque, sem o assentimento dos batizandos, que desconheciam o significado da cerimônia, porque ele não lhes fora explicado em sua língua.

A atuação dos missionários obedecia a preceitos ditados pelas circunstâncias: em primeiro lugar, se ocupavam dos enfermos, assistindo antes os que chegavam batizados e, depois, os não-cristãos, que recebiam uma instrução sumária, a fỉm de serem batizados com a maior brevidade possível. Depois da cerimônia, os neófitos recebiam uma imagem que deveriam usar ao pescoço, para serem facilmente identificados. Em seguida, os padres se ocupavam dos sãos, instruindo brevemente aqueles que não haviam recebido o batismo ou cujo batismo era por eles considerado inválido. Depois, os reuniam em lugar decente, separavam-nos por grupos linguísticos e os batizavam, atribuindo a cada qual um nome cristão. Sempre com o recurso a intérpretes, lhes transmitiam ainda, para finalizar, os princípios básicos do Catolicismo.

Os argumentos invocados pelos opositores dos jesuítas eram, em resumo, cinco: 1. ${ }^{\circ}$ os batismos ministrados nos portos de embarque deviam ser tidos como válidos; $2 .^{\circ}$ rudes e boçais, os escravos podiam ser equiparados a crianças e, como tal, não deveria se exigir deles que entendessem o significado do batismo, nem seu consentimento era necessário para que ele lhes fosse ministrado; $3 .^{\circ}$ os batismos realizados pelos jesuítas à chegada não obedeciam às regras da Igreja que, entre outras coisas, determinavam que nenhum negro fosse batizado sem saber rezar, ao menos, duas orações: Pai Nosso e Credo; . $^{\circ}$ os escravos batizados pelos jesuítas em casa de seus senhores não iam, depois disso, à igreja para participar nos ritos e solenidades prescritos como obrigatórios para os fiéis e, não o fazendo, esqueciam com facilidade os ensinamentos recebidos; $5 .^{\circ}$ os batismos de grupo, cuja ocorrência tinha lugar em casas particulares, feriam a dignidade da cerimônia, ligada à sua realização em uma igreja e, além disso, ao fazê-los, os jesuítas não tinham em atenção as declarações produzidas por alguns senhores, que 
afirmavam estarem já os seus escravos batizados, colocando, assim, em causa a autoridade dos mesmos e, em última análise, a própria ordem escravocrata.

A estas críticas, Alonso de Sandoval respondia dizendo que as ações empreendidas pelos jesuítas contribuíam para salvar as almas dos escravizados e, como tal, não poderiam deixar de ser consideradas válidas. Além de outros argumentos, denunciava os maus tratos a que estes se viam sujeitos durante a travessia do Atlântico, sua debilidade à chegada e os perigos que os esperavam após o desembarque em Cartagena. Em sua opinião, estas eram razões mais do que suficientes para abreviar o batismo dos que chegavam. Aliás, a experiência mostrava que não era conveniente adiálo até que estes se fizessem ladinos, porque, entretanto, muitos deles começavam a praticar atos reservados aos cristãos, com os quais se misturavam, chegando a se confessar e a comungar sem serem batizados. A atuação dos jesuítas se apoiava, de resto, em privilégios outorgados à Companhia pelo próprio papa.

Por outro lado, os padres de Cartagena teriam em seu poder um documento oficial, alegadamente assinado por "todos los capitanes y señores de armasones" que nos anos anteriores para ali haviam transportado escravos, no qual se descrevia a forma como em Cacheu eram batizados os negros boçais antes de serem embarcados:

es que estan todos juntos en $1<\mathrm{os}>$ navio[s] aherrojados con sus grillos corrientes y demas priziones debaxo de cubiert[a] ba el padre cura o vicario con su sobrepelis y estola y haze que todos salgan de la encubierta y ajuntados alli sin quita[r]lles las priziones toma dos niños y los baptiza solemnemente haziendo en ellos todos los ritos y seremonias que nuestra santa madre la Yglésia acostumbra en el baptismo solemne y quando llega el tiempo de les hechar el agua despues de aversela hechado a los dos niños llama a todos los adultos los quales la ban reçibiendo de uno en uno hombres y mugeres asi haerrojados y priçionados como estavan con sus corrientes debaxo de cubierta antes que de alli los sacassen sin aver precedido antes (ques en donde consiste la dificultad del negocio del baptismo) enseña[n]ça ninguna por ninguna suerte ny manera ni pedidoles su consintimiento por ningun caso ni ellos aver tinido lugar ny ocazion de aver entendido sabido o comprehendido que fuesse el santo baptismo que recibia[n] ny nadie averselo dicho por ser de tan diferentes y diversas y extraordinarias ${ }^{17}$ castas y lenguas como son y asi como ban recibiendo el agua por su orden buelven baxando debajo de cubierta tan moros como salieron por no saver lo que recivian ny aver dado su consentimiento a ello. $^{18}$

Ora, dizia para finalizar o jesuíta, ainda que ignorassem as línguas europeias, os habitantes da África subsaariana não eram desprovidos de capacidade, possuindo

\footnotetext{
17 Riscado: "partes".

${ }^{18} \mathrm{O}$ documento em questão seria, depois, integralmente transcrito em SANDOVAL, 1987 [1627], p. 384386.
} 
vontade própria e discernimento. Logo, para que seu baptismo fosse válido, era indispensável obter o consentimento prévio dos escravizados, tal como defendiam numerosos autores e a própria Bíblia, em cuja autoridade se fundamentavam.

A atuação desenvolvida a partir de Cartagena pelo padre Alonso de Sandoval e, em Cabo Verde, pelos jesuítas da missão local, igualmente empenhados na assistência aos cativos, acabaria por chamar a atenção das autoridades metropolitanas para a questão do batismo dos escravizados (SANDOVAL, 1987 [1627], p. 288-292, 382-383 e 386-388). Em 1622, Felipe IV mandou reunir em Lisboa uma junta constituída, entre outros, por teólogos, com o objetivo de analisar as circunstâncias em que tinha lugar o batismo dos escravizados na Guiné e em Cabo Verde. Segundo as determinações emanadas da reunião, eles deveriam ser batizados em Cacheu, onde os navios que os transportavam permaneciam durante mais tempo do que em Santiago, e os missionários poderiam impedir o embarque dos cativos até que eles estivessem em condições de receber o batismo, a fim de evitar a nulidade do mesmo e que eles fossem batizados segunda vez ao chegarem a seu destino (GONÇALVES, 1996, p. 104-106; 2000, p. 160-162).

O assunto não terminaria, porém, aqui. Uma década mais tarde, Lourenço de Mendonça, que então era o responsável pela prelazia do Rio de Janeiro, solicitava a ereção da cidade a sede de bispado. Um dos argumentos por ele invocados consistia na necessidade de dar remédio a algumas questões com que a Igreja ali se via confrontada, a primeira das quais, dizia, era "para com grande zelo tratar dos batismos dos negros adultos vindos de Angola, que são infinitos, porquanto, após minuciosas informações de Angola e declaração dos ditos negros, consta que não souberam o que receberam" (apud RUBERT, 1976, p. 25). Uma afirmação que, embora negasse as impressões recolhidas por Alonso de Sandoval, poderia denotar um exagero do prelado, desejoso de envergar a mitra episcopal. A referência a um número infinito de escravos chegados de Angola parece, aliás, confirmá-lo. ${ }^{19}$

\footnotetext{
${ }^{19}$ No entanto, um século mais tarde, os problemas persistiam, como pode se constatar pela declaração prestada por Luís José Correia de Sá, fazendeiro em Campos dos Goytacazes, a Gaspar Gonçalves de Araújo, comissário do Santo Ofício, na qual lhe dava conta das queixas recebidas de um escravo seu (cuja origem desconhecemos), alegadamente subornado por um português que o proprietário acolhera em sua fazenda, o qual the oferecera uma galinha para com ele praticar atos homossexuais: "e pelas suas respostas vim a acentar que he moralmente impossivel que hum negro novo, que por naõ entender ainda a nossa lingoa, naõ sabe nem o Padre Nosso, e por esta cauza nem elle, nem seus companheyros saõ ainda baptizados, levantasse taõ grande testemunho, ainda quando elle naõ contava isto, por entender o mal que hera, mas sómente para me dizer, que naõ cuydase eu se lhe visse esta tal galinha, que elle a tinha furtado". ANTT, TSO, IL, Processos, n. 15483, 25/07/1729, fl. não num. (grifo nosso). Ao analisar os registros de batismo de escravos adultos nas freguesias urbanas do Rio de Janeiro,
} 
Dízimo: O batismo não possuía apenas um significado simbólico. Além de assinalar a entrada do catecúmeno na comunidade dos crentes, lhe outorgava um conjunto de responsabilidades que iam para além do cumprimento dos preceitos religiosos e da obediência à Igreja e ao Estado. Traduziam-se, também, no pagamento obrigatório do dízimo que, como é sabido, constituía uma importante fonte de rendimentos para a Igreja e, especialmente no que se refere ao Ultramar, para o monarca, na sua qualidade de administrador da Ordem de Cristo.

Durante o governo de d. Francisco Inocêncio de Sousa Coutinho (1726-1780) em Angola, alguns de seus habitantes procuraram se eximir ao pagamento deste tributo eclesiástico alegando que não eram cristãos, mas sim gentios. O governador tomou as medidas ao seu alcance para facilitar os batismos, informando do fato as autoridades metropolitanas, a quem solicitou o envio de missionários, de que na colónia havia "grande falta". D. Francisco tinha plena consciência que os gentios não estavam sujeitos ao pagamento do dízimo, mas adiou até onde lhe foi possível a publicação de uma ordem que os declarasse isentos por temer que, depois de o fazer, "muitos, e talvez todos recuzássem absolutamente pela sua brutalidade o bautismo". ${ }^{20}$

O desenvolvimento da colonização e seus próprios escrúpulos acabariam por ditar a isenção oficial do pagamento, ${ }^{21}$ mas sete anos depois de expedir o primeiro aviso, o governador se dirigia, de novo, às autoridades metropolitanas para solicitar providências imediatas na matéria. ${ }^{22}$ Se nada se fizesse, alertava, os prejuízos seriam graves, tanto para a religião, como para a Fazenda de Sua Majestade. O número de batismos iria por certo decair, tal era o "ódio" dos negros e a sua "brutalidade": de fato, a maioria dos adultos se batizava "sem a necessária crença, e sem o exterminio dos seus primeiros abuzos", mas, por outro lado, as crianças mortas na tenra infância “[aproveitavam] inteiramente a graça do sacramento" e os benefícios a ele inerentes,

durante o século XVIII, Mariza de Carvalho Soares (1998, p. 7; 2000, p. 110-112) verificou que a esmagadora maioria dos que recebiam o batismo na cidade era proveniente da África Ocidental (2063 de um total de 2660): os registros correspondentes a escravos oriundos da África Centro-Ocidental eram raros, o que confirma as informações veiculadas por Alonso de Sandoval no início do séc. XVII, e, no caso destes, o baptismo era feito sub condicione, para acautelar a possibilidade de já terem recebido o sacramento.

${ }^{20}$ ANTT, MR, EXP, mç. 600, n. 10, 30/06/1765: carta enviada de Luanda por d. Francisco Inocêncio de Sousa Coutinho a Francisco Xavier de Mendonça Furtado, secretário de Estado dos Negócios da Marinha e Domínios Ultramarinos.

21 ANTT, MR, EXP, mç. 600, doc. não num., 04/05/1772: carta circular enviada por d. Francisco Inocêncio de Sousa Coutinho às autoridades distritais de Angola.

22 ANTT, MR, EXP, mç. 600, doc. não num., 05/05/1772: carta enviada de Luanda por d. Francisco Inocêncio de Sousa Coutinho ao Marquês de Pombal, Sebastião José de Carvalho e Melo (as citações aqui apresentadas foram retiradas deste documento).

Revista Escritas do Tempo - v. 1, n. 3, nov/2019-fev/2020 - p. 8-33 
pelo que qualquer alteração a esse respeito teria "huma gravissima consequencia". Com a isenção do dízimo aos gentios, a arrecadação da Coroa também seria prejudicada, ainda mais porque não havia condições para controlar eficazmente quem devia e não devia pagar, isto é, quem era e não era cristão.

Para solucionar o problema, seria, portanto, necessário que fossem enviados missionários para a colónia, tanto mais que os seculares eram relapsos no cumprimento de suas funções - "dos parochos do paîz", dizia o governador, "se nam póde prudentemente esperar o fructo necessário". ${ }^{23}$ Ainda que as autoridades metropolitanas acatassem seu pedido, os resultados desejados levariam algum tempo a ser alcançados. D. Francisco de Sousa Coutinho sugeria assim, por último, uma medida que, a se concretizar, não deixaria de provocar reações adversas, designadamente por parte da Igreja: a conversão do dízimo em tributo secular para, desta forma, se poder exigir que também o pagassem os gentios submetidos à Coroa portuguesa.

No Brasil, a questão assumia contornos distintos, como se depreende de uma carta enviada ao rei (Felipe II) pela câmara da Paraíba (atual João Pessoa): os índios, se dizia, "não eram capazes de receber lei, nem prematica, que se lhes pusesse: pois ate o proprio do dizimo, que hera pensão de direito divino, não pagavão". ${ }^{24}$ Neste caso, a solução teria passado pelo encabeçamento do tributo, com a fixação prévia do montante a arrecadar (FIGUEIREDO, 2004, p. 75-76).

A julgar pelas informações contidas no Diretório dos Índios, de meados do século XVIII, os resultados obtidos devem ter sido, no entanto, muito escassos:

para que Deos Nosso Senhor felicite, e abençôe o trabalho dos indios na cultura das suas terras, será preciso desterrar de todas estas povoaçoens o diabolico abuso de se naõ pagarem dizimos. (...) Sendo esta obrigaçaõ commua a todos os catholicos, he taõ escandalosa a rusticidade, com que tem sido educados os indios, que naõ só naõ reconheciaõ a Deos com este limitadissimo tributo, mas até ignoravaõ a obrigaçaõ que tinhaõ de o satisfazer (DIRECTORIO, 1758, p. 12).

O documento, que reforçava as disposições contidas em uma pastoral anteriormente publicada pelo bispo do Pará sobre esta "importantissima materia", continha, aliás, instruções detalhadas sobre a cobrança do tributo, destinadas a garantir uma arrecadação eficiente. Daí em diante, os indígenas ficariam, assim, obrigados a

\footnotetext{
${ }^{23}$ Sobre as críticas do governador em relação ao comportamento dos párocos, ver: ANTT, MR, EXP, mç. 600, n. 10, 20/06/1765: cópia de uma carta enviada por d. Francisco Inocêncio de Sousa Coutinho aos capitães-mores dos presídios de Angola.

${ }^{24}$ ANTT, CC, Parte I, mç. 115, doc. 108, 19/04/1610, fl. não num.
} 
entregar ao Estado um décimo de tudo o que produzissem; os gêneros por eles adquiridos estariam sujeitos a uma tributação idêntica.

No entanto, as dificuldades até então registradas permitiam antever que a colocação da medida em prática não seria tarefa fácil, principalmente "emquanto se naõ [destinasse] methodo claro, racional, e fixo, para se cobrarem os dizimos sem detrimento dos lavradores, e nem prejuizo da Fazenda Real". Assim, as roças cultivadas pelos indígenas deveriam ser periodicamente inspecionadas, a fim de se calcular o volume da produção anual para, em seguida, fixar o montante a ser pago pelo cultivador. Estes valores seriam registrados em livro próprio; noutro, se inscreveriam os nomes dos pagadores e as parcelas pagas por cada um. Os produtos recolhidos deveriam ser cuidadosamente armazenados e seu transporte realizado sob estrita vigilância. Dois séculos após o início da colonização, o poder metropolitano estava assim, finalmente, determinado a acabar com as fugas e descaminhos na cobrança dos dízimos (DIRECTORIO, 1758, p. 12-15).

Os indígenas não eram, aliás, os únicos que procuravam se furtar ao pagamento deste tributo. Apesar das penas previstas na lei para os faltosos e dos "terríveis castigos" em que incorriam, vindos do próprio Deus, que os fulminaria com a pobreza e a esterilidade, além de outras desgraças, havia muitos colonos que, alheios também aos "prêmios temporais e eternos" que lhes estavam prometidos se cumprissem rigorosamente o "preceito divino" de pagar os dízimos, se esquivavam a fazê-lo (VIDE, 2010 [1719], p. 300-308).

Uma das dificuldades em determinar o número de indivíduos escravizados existente no território brasileiro e sua evolução estaria, de resto, ligada à fuga aos dízimos. Como, em alguns casos, o montante a pagar era não de um décimo, mas certa quantia, estabelecida em função do número de cativos, os proprietários tinham todo o interesse em declarar um número inferior àquele de que, efetivamente, eram possuidores. Até mesmo porque, além do dízimo, tinham de pagar pela confissão de seus escravos para cumprimento da desobriga pascal. Por outro lado, o batismo também obrigava a despesas por parte dos senhores: no século XVIII, a Igreja cobrava, em média, 300 a 600 réis por cada adulto batizado e 50 a 100 réis pelas crianças e lactentes (PINTO \& CARREIRA, 1981, p. 178).

No escravismo moderno, as preocupações de natureza espiritual, ligadas à propagação do Catolicismo e à salvação das almas dos cativos, aparecem, assim, estreitamente associadas a interesses de ordem material - da própria Coroa, que recebia

Revista Escritas do Tempo - v. 1, n. 3, nov/2019-fev/2020 - p. 8-33 
contrapartidas econômicas do tráfico e, através de cobranças várias, absorvia uma parcela dos lucros resultantes do trabalho escravo, beneficiando, igualmente, do crescimento exponencial de seus súditos, cujas contribuições reforçavam os cofres do Estado; dos particulares, traficantes e proprietários de escravos; e, finalmente, da Igreja que, com o crescimento do número de fiéis, via suas receitas aumentarem, consolidando o poder e influência que detinha na sociedade.

As reflexões produzidas pelos autores da época - designadamente aqueles ligados à Igreja - evidenciam a preocupação em conjugar as aspirações materiais com objetivos de natureza espiritual e religiosa, submetendo-as a um conjunto de regras que, em última análise, deveriam garantir o funcionamento harmonioso do sistema, promovendo a melhoria das condições de vida dos escravizados sem pôr em causa os interesses dos proprietários.

Além de veicular os interesses oficiais, do Estado, o discurso da Igreja lhes conferia autoridade moral, contribuindo, desde logo, para sua concretização prática. Mas, ao fazê-lo, procurava defender, também, os interesses próprios da instituição: quer os de ordem espiritual, quer os de ordem material, ligados à sustentação econômica da Igreja e de seus membros.

A ação prática reforçava o sentido do discurso: ao mesmo tempo que conquistavam novos fiéis para o grêmio da Igreja, os missionários granjeavam súditos para a Coroa portuguesa; párocos, confessores e pregadores recebiam instruções para exortar os cristãos ao pagamento dos dízimos (VIDE, 2010 [1719], p. 301-302); a submissão aos poderes constituídos e o respeito pela ordem vigente eram pregados em todos os altares e, com especial ênfase, aos escravizados, cujas agruras na Terra seriam recompensadas com a bem-aventurança eterna.

Nestas condições, a oposição ao escravismo exigiria uma "considerável independência da mente" (DAVIS, 2001, p. 214-215). De uma maneira geral, o sistema em si não foi posto em causa; apesar disso, a escravização do homem pelo homem estava longe de ser uma questão pacífica para o pensamento cristão, dando lugar a tensões cujo apaziguamento seria, muitas vezes, difícil.

As contradições ideológicas da época, em grande parte resultantes da oposição entre os valores para os quais remetia o conceito de «honra» (nobre), proveniente da Idade Média, e os interesses ligados ao conceito moderno de «proveito» (burguês) (SANTOS, 1992, p. 69-73), influenciaram, também, a discussão em torno do 
escravismo, condicionando, em maior ou menor grau, as posições assumidas pelos autores.

A maioria procurou conciliar os princípios doutrinários, de natureza teológica e moral, com as considerações ligadas aos interesses de ordem econômica e política, buscando um compromisso - necessariamente frágil - entre o humanitarismo cristão e as novas práticas associadas ao desenvolvimento do capitalismo comercial e da concorrência à escala global. Outros, muito menos numerosos, mas também mais independentes ou, no mínimo, idealistas, não se deixariam, porém, amedrontar ante a perspectiva de afrontar os poderes constituídos e, questionando abertamente a legitimidade do sistema, denunciaram a iniquidade dele. No entanto, quase todos pagariam um preço por se manterem fiéis a sua própria consciência.

\section{Referências}

ANTT, AJCJ, CJ, mç. 56, n. 60, 07/06/1611-11/05/1612

ANTT, CC, Parte I, mç. 115, doc. 108, 19/04/1610

ANTT, MNEJ, mç. 69, n. 5, 1748

ANTT, MR, EXP, mç. 600, n. 10, 30/06/1765; doc. não num., 04/05/1772; doc. não num., 05/05/1772

ANTT, TSO, IL, Processos, n. 3641, 24/05/1781-21/08/1786; n. 5635, 14/05/178420/03/1786; n. 15483, 25/07/1729

AGATE, Leonard T. Slavery - Christian. In: HASTINGS, James (Ed.). Encyclopaedia of Religion and Ethics. v. 11. Edinburgh; Nova York: T. \& T. Clark - Charles Scribner's Sons, 1974.

BEBIANO, Rui. A pena de Marte: escrita da guerra em Portugal e na Europa (sécs. XVI-XVIII). Coimbra: Minerva, 2000.

BRÁSIO, António. O espírito missionário de Portugal na época dos Descobrimentos. Lusitania Sacra, Lisboa, s. 1, t. 5 (1960-1961), p. 101-120, 1961.

BRETT, Stephen F. Slavery and the Catholic tradition: rights in the balance. Nova York; etc.: Peter Lang, 1994.

CARVALHO, José Geraldo Vidigal de. A escravidão: convergências e divergências. Viçosa: Ed. Folha de Viçosa, 1988.

CICCOTTI, Ettore. Le déclin de l'esclavage antique. Paris: Librairie des Sciences Politiques et Sociales, 1910.

COPELAND, M. Shawn. Black theology. In: DWYER, Judith A. (Ed.). The new dictionary of Catholic social thought. Collegeville, MN: The Liturgical Press, 1994. 
CORCORAN, Gervase. Saint Augustine on slavery. Roma: Institutum Patristicum «Augustinianum», 1985.

COSTA, Emília Viotti da. A abolição. São Paulo: Editora UNESP, 2008.

COUTINHO, José Joaquim da Cunha de Azeredo. Analyse sobre a justiça do commercio do resgate dos escravos da costa de Africa [...]. Lisboa: Na Nova Officina de João Rodrigues Neves: 1808.

Concordância das leis de Portugal e das bullas pontifícias, das quaes humas permittem a escravidão dos pretos d'Africa, e outras prohibem a escravidão dos indios do Brazil. Lisboa: Na Nova Officina de João Rodrigues Neves, 1808.

DAVIS, David Brion. O problema da escravidão na cultura ocidental. Rio de Janeiro: Civilização Brasileira, 2001.

DIRECTORIO, que se deve observar nas povoaçoens dos indios do Pará, e Maranhaõ em quanto Sua Magestade naõ mandar o contrario. Lisboa: Na Officina de Miguel Rodrigues, 1758.

FIGUEIREDO, José Ricardo. Modos de ver a produção do Brasil. São Paulo; Campinas: EDUC - Editora Autores Associados, 2004.

FINLEY, Moses I. Escravidão antiga e ideologia moderna. Rio de Janeiro: Graal, 1991.

GARNSEY, Peter. Ideas of slavery from Aristotle to Augustine. Cambridge; Nova York; Melbourne: Cambridge University Press, 1999.

GENOVESE, Eugene D. Roll, Jordan, roll: the world the slaves made. Nova York: Vintage Books, 1976.

GILBERTSON, Albert N. Slavery - Primitive. In: HASTINGS, James (Ed.). Encyclopaedia of religion and ethics. Vol. 11. Edinburgh; Nova York: T. \& T. ClarkCharles Scribner's Sons, 1974.

GOLDENBERG, David M. The curse of Ham: race and slavery in early Judaism, Christianity, and Islam. Princeton; Oxford: Princeton University Press, 2003.

GONÇALVES, Nuno da Silva. Os jesuítas e a missão de Cabo Verde (1604-1642). Lisboa: Brotéria, 1996.

Escravatura. In: AZEVEDO, Carlos A. Moreira (Dir.); JORGE, Ana Maria C. M. et al. (Coord.). Dicionário de história religiosa de Portugal. Vol. 2. Lisboa: Círculo de Leitores, 2000.

HAYNES, Stephen R. Noah's curse: the biblical justification of American slavery. Oxford; Nova York: Oxford University Press, 2002.

JOHNSON, Sylvester A. The myth of Ham in nineteenth-century American Christianity: race, heathens, and the people of God. Nova York: Palgrave Macmillan, 2004. 
JOLY, Fábio Duarte. Estoicismo e escravidão no pensamento de Sêneca. Phoînix, Rio de Janeiro, a. 13, p. 98-114, 2007.

JORDÃO, Levy Maria. Bullarium patronatus Portugalliae regum [...]. T. I. Lisboa: Tipografia Nacional, 1868.

KAPP, Amanda Cieslak. Fernando Oliveira e o humanismo português no séc. XVI. Dissertação (Mestrado em História), Universidade Federal do Paraná, Curitiba, 2013.

LINCOLN C. Eric; MAMIYA, Lawrence H. The black Church in the African American experience. Durham, NC: Duke University Press, 1990.

MAGALHÃES, Joaquim Romero. Os territórios africanos. In: BETHENCOURT, Francisco; CHAUDHURI, Kirti (Dir.). História da expansão portuguesa: o Brasil na balança do império, 1697-1808. Vol. 3. Lisboa: Temas e Debates, 1998.

MARQUES, João Martins da Silva. Descobrimentos portugueses: documentos para a sua história. Vol. I. Lisboa: Instituto para a Alta Cultura: 1944.

MEDINA, João. África cativa. A escravidão vista e julgada pelos europeus, nomeadamente pelos portugueses (sécs. XV a XIX). In: MEDINA, João; HENRIQUES, Isabel Castro. A rota dos escravos: Angola e a rede do comércio negreiro. Lisboa: CEGIA, 1996.

MERCADO, Tomás de. Suma de tratos y contratos [1571]. Ed. de Nicolás SÁNCHEZALBORNOZ. Madrid: Instituto de Estudios Fiscales: 1977.

NABUCO, Joaquim. O abolicionismo [1883]. São Paulo: Publifolha, 2000.

PIMENTEL, Maria do Rosário. A expansão ultramarina e a lógica da guerra justa. In: MENESES, Avelino de Freitas de; COSTA, João Paulo Oliveira e (Coord.). O reino, as ilhas e o mar-oceano: estudos em homenagem a Artur Teodoro de Matos. Vol. 1. Lisboa; Ponta Delgada: UNL/FCSH/CHAM - Universidade dos Açores, 2007.

PINTO, Françoise Latour da Veiga (colab. de António CARREIRA). A participação de Portugal no tráfico negreiro - forças em presença, movimentos de opinião no seio da sociedade portuguesa, impacte do tráfico no desenvolvimento socioeconómico de Portugal. In: VVAA. O tráfico de escravos negros, sécs. XV-XIX. Lisboa: Edições 70, 1981.

RABOTEAU, Albert J. Slave religion: the "Invisible Institution" in the Antebellum South. Oxford; Nova York; etc.: Oxford University Press, 2004.

RUBERT, Arlindo. O prelado Lourenço de Mendonça, $1 .^{\circ}$ bispo eleito do Rio de Janeiro. Revista do IHGB, Rio de Janeiro, v. 311, p. 13-33, abr./jun. 1976.

RUSSELL-WOOD, A. J. R. Iberian expansion and the issue of black slavery: changing Portuguese attitudes, 1440-1770. The American Historical Review, Chicago, MA, v. 83, n. 1, p. 16-42, fev. 1978. 
SANDOVAL, Alonso de. Un tratado sobre la esclavitud (De Instauranda Æthiopium Salute) [1627]. Introd., transcrição e trad. de Henriqueta VILA VILAR. Madrid: Alianza Editorial, 1987.

SANTOS, João Marinho dos. A ideologia da expansão portuguesa: séculos XV e XVI. Revista de História das Ideias, Coimbra, v. 14, p. 69-73, 1992.

SIERRA BRAVO, Restituto. Doctrina social y económica de los Padres de la Iglesia: colección general de documentos y textos. Madrid: COMPI - Compañía Bibliografica Española S.A., 1967.

SIQUEIRA, Sônia Aparecida. A escravidão negra no pensamento do bispo Azeredo Coutinho - contribuição ao estudo da mentalidade do último inquisidor geral. In: COLÓQUIO INTERNACIONAL DE ESTUDOS LUSO-BRASILEIROS, V, 1963, Coimbra. Atas... Vol. 3. Coimbra: [s.n.], 1965. p. 147-213.

SMITH, Nicholas D. Aristotle's theory of natural slavery. The Phoenix, Toronto, v. 37, n. 2, p. 109-122, verão/1983.

SOARES, Mariza de Carvalho. Mina, Angola e Guiné: nomes d'África no Rio de Janeiro setecentista. Tempo, Niterói, RJ, v. 3, n. 6, p. 151-165, dez./1998.

Devotos da cor: identidade étnica, religiosidade e escravidão no Rio de Janeiro, século XVIII. Rio de Janeiro: Civilização Brasileira, 2000.

SPICQ, C. Le vocabulaire de l'esclavage dans le nouveau testament. Revue Biblique, t. 85 , n. 2, p. 201-226, abr./1978.

VIDE, Sebastião Monteiro da. Constituições primeiras do arcebispado da Bahia [1719]. Estudo introdut. e ed. de Bruno FEITLER e Evergton Sales SOUZA; Istvan JANCSÓ e Pedro PUNTONI (Org.). São Paulo: Edusp, 2010.

WHITFORD, David M. The curse of Ham in the early modern era: The Bible and the justifications for slavery. Burlington, VT: Ashgate Publishing Ltd., 2009.

Artigo recebido em 15 de janeiro de 2020. Aprovado em 24 de fevereiro de 2020.

Revista Escritas do Tempo - v. 1, n. 3, nov/2019-fev/2020 - p. 8-33 